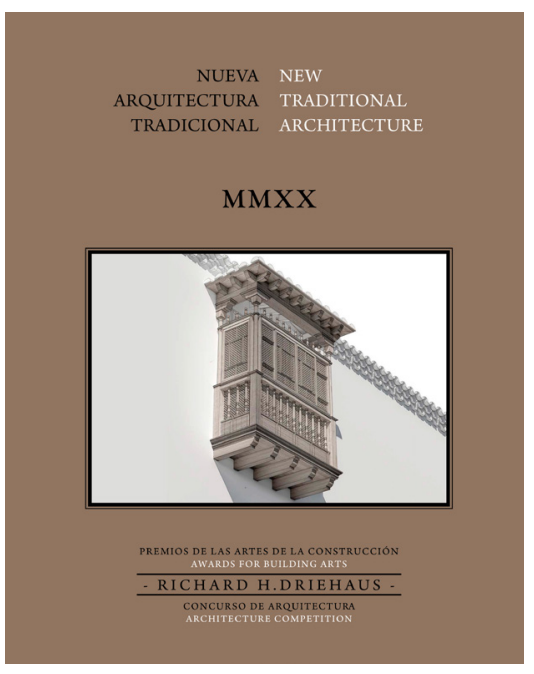

\section{Lessons from the Past, a Pathway to the Future}

\section{Lecciones del pasado, una vía hacia el futuro}

\section{Lições do passado, um caminho para ofuturo}

\section{Carol Wyant}

Over time, as humans have come together to survive and thrive, the places they settled became a reflection of physical topography and climate, as well as the activities of the people living there. Within a region there may be similarities among places, but also slight differences. Further away, in different geographical circumstances settlements might be quite different.

Such rich cultural history provides us an identity, but also lessons for how to live sustainably into the future. New Traditional Architecture $M M X X$ recognizes the importance of our cultural and built tradition and explores these larger themes.

Each municipality has a physical pattern of streets, lots and blocks. The rules - first unwritten yet understood and now written into legal codes determine the placement and details of public open space and private structures. The resulting urban design conveys the character and sense of place that is "somewhere" rather than "anywhere." Essential to retaining the character we value are the artisans who provide the masonry, carpentry, metal work, glass work and building finishes for each given location.

In order to retain our past and learn from it, we must identify and honor masters of urban design and the building arts. This book does just that.

It illustrates the application of urban designexpertise to challenges presented by local municipalities wishing to build upon or heal heritage locations. The 2-stage 2019-2020 Richard H. Driehaus Architecture Competition first chose three municipalities from among many applications seeking urban design proposals for locations within their community. During the second stage design teams proposed solutions and the winning concepts are presented here.

Equally important, master artisans are essential to implement design concepts true to the history and culture of place. Using natural materials for building façades, structures and elements they not only retain the beauty of the past, but they also demonstrate building in a sustainable way for the future. The four Richard H. Driehaus Building Arts masters selected in 2020 are exemplars of their respective crafts. In addition, one master is chosen each year to pass his or her knowledge to an apprentice.

In conclusion, those of us supporting these values may be unrecognized or valued in our respective locations, but together, through the activities outlined in this book, we expand the possibilities for the success of New Traditional Building, Architecture and Urbanism.

Alejandro García Hermida (ed.) Nueva Arquitectura Tradicional - New Traditional Architecture MMXX

INTBAU España, 2020 